\title{
Legal Protection for Nurses during the COVID-19 Pandemic
}

\author{
Mulyana $^{1}$, Azis Budianto ${ }^{2}$ \\ \{anaunborr@gmail.com ${ }^{1}$, azis_budianto@borobudur.ac.id $\left.{ }^{2}\right\}$ \\ Universitas Borobudur, Jakarta, Indonesia ${ }^{1,2}$
}

\begin{abstract}
Attendants are clinical work force who are at the bleeding edge of taking care of the Covid 19 pandemic. During this crisis, what is the lawful assurance for medical attendants during the Covid 19 pandemic? By using a qualitative approach with normative juridical methods, accompanied by data collection utilizing a literature study, it was found that there is legal protection for nurses who are carrying out their duties. The applicable legislation provides obvious provisions for legal protection for nurses. However, derivative stipulations are needed that regulate the potential caused during the Covid-19 pandemic.
\end{abstract}

Keywords: Covid-19; Nurses; Legal Protection

\section{Introduction}

Toward the finish of 2019, the world was hit by the rise of another illness, for example, pneumonia beginning from China as Covid-19. In light of data from the nearby Chinese specialists, the dominance of patients who gotten the sickness came from the hugest creature market in Wuhan City, China, which sells different types of live creatures. On March 11, 2020, WHO (World Health Organization) expressed that Covid-19 was named a pandemic as articulated in Presidential Decree No. 12 of 2020 concerning the Designation of Non-Natural Disasters for the Spread of Corona Virus Disease 2019 (Covid-19) as a National Disaster. The Covid-19 pandemic that happens worldwide for over a year since it was found. WHO noticed that there were 13,446,538 affirmed instances of Covid-19 on April 12, 2021, with passings contacting 2,927,922 individuals. Regardless in the domain of Indonesia, there has been a spread of the Covid-19 infection where as indicated by the records of the Indonesian Ministry of Health, until April 11, 2021, the affirmed survivors of Covid-19 were 1,566,995 individuals with the loss of life of upwards of 42,530 individuals.[1] In all countries affected by the Covid-19 pandemic, fatalities were not only for patients affected by the Covid-19 virus but for non-Covid-19 patients, where according to BBC research, it was found that 130,000 nonCovid-19 patients died due to not receiving proper health services. This number is very huge when contrasted with the period before the Covid-19 pandemic.

The beginning of the Covid is known to have first showed up in the creature and fish market in Wuhan city, China, toward the finish of December 2019. Later it was accounted for that numerous patients were experiencing this infection, and it was viewed as identified with the creature and fish market. The first people who fell ill from this virus were also known to 
be traders at the market, in which the wholesale business for animals and seafood sold wild animals such as snakes, bats, and chickens. They speculate that this new Covid more likely than not comes from snakes. It was thought that this infection spread from creatures to people, and afterward from one people to another. China was recorded as the country that originally detailed instances of COVID-19 on the planet. Toward the finish of 2019, the World Health Organization (WHO) office in China got a warning of a sort of pneumonia whose cause was obscure. The intense respiratory contamination that assaults the lungs was identified in Wuhan city, Hubei Province, China. As per specialists, a portion of the patients were brokers working at the Huanan fish market.[2]

These problems are no exception in Indonesia, where the Covid-19 pandemic period with the relatively long period of spreading the Covid-19 virus has resulted in an increasing number of visitors who need health service facilities in intensive care units while the available facilities are not proportional to the number of patients who need it, especially for those who need health services for non-Covid-19 patients because the health service is filled by Covid-19 patients. Even if there are facilities for non-Covid-19 patients in the intensive care unit, the patient is required to run tests as a requirement to get health services from these problems resulting in the impression of rejection of non-Covid-19 patients.[3] But, when a non-Covid19 patient is in a critical condition who urgently needs help immediately, and if not help them, it can cause death for the patient. According to the Indonesian Hospital Association stating that when patients affected by positive Covid-19 cases in Indonesia continue to grow, all health service providers which providing intensive care units in both Java and Bali will no longer be able to accommodate both Coronavirus and non-Covid-19 patients who require wellbeing administrations in escalated care units.

Wellbeing administrations did by clinical staff can be supposed to be practically inadequate because of the enormous number of patients who are proclaimed positive for COVID-19. In view of the portrayal, it will be examined how the underlying spread of the infection so rapidly in Indonesia, and how wellbeing administrations for Indonesian individuals with the data delay in unveiling the spread of the COVID-19 infection.[2] One of the perspectives that have gotten the huge effect from this pandemic is in the wellbeing area. Issues in the wellbeing area are progressively obvious in the time of the Covid-19 pandemic in Indonesia. The current condition is a worry for the whole local area identified with endeavors to control and defeat this Covid-19 Pandemic in Indonesia. It incorporates clinical and other wellbeing experts. The passings of clinical staff, particularly specialists and attendants, are very enormous as casualties of the fierceness of Covid 19. During this crisis, what is the lawful security for medical caretakers during the Covid 19 pandemic? This paper will depict extensively identified with legitimate insurance for medical attendants during the Covid 19 Pandemic.

\section{Method}

This research is juridical-normative. The normative legal research method [4] can be interpreted as legal research at the level of norms, rules, principles, theories, philosophies, and the rule of law to find solutions or answers to problems in the form of a legal vacuum, norm conflict, or norm ambiguity. Thus, the normative legal research method has the characteristics of library research [5] which is different from the empirical (non-doctrinal) research method is characterized by field research. Analysis of Legal Material Sources in this study found a vagueness of legal norms. The data analysis used in normative legal research is qualitative,[6] 
namely data analysis by describing quality data in the form of regular, sequential, logical, nonoverlapping sentences, and effective, thus facilitating data interpretation and understanding of analysis results.

\section{Discussion}

People are animals made by God who since birth, have fundamental privileges, in particular the right to life, the option to be secured, the option to be free and different freedoms. In this way, every person has the option to be secured, remembering for the life in the State. As such, every resident will get assurance from the State. Law is a way to get it going with the goal that the hypothesis of legitimate security arises.[7] It is the security of poise and basic freedoms dependent on lawful arrangements by the state device. In this way, taking into account that Indonesia is known as a condition of law, then, at that point, legitimate insurance is an outright ideal for each resident and is a commitment that should be completed by the public authority. Legitimate security is a work to ensure an individual's advantages by apportioning some capacity to him to act to his greatest advantage. Besides, it is likewise expressed that one of the qualities and the motivation behind the law is to ensure the local area. Subsequently, legitimate insurance for society should be acknowledged as lawful conviction.

Legal protection pursued through legislation has an underlying legal principle. Likewise, legal protection is taken through efforts to make and include steps through legislation that has a purpose, the scope of which is planned through strategies and policies. All of these things can be found in every piece of legislation that is held the same goal, namely legal protection. Pound classifies the interests protected by law into 3 (three) main categories, including public interests, social interests, and private interests.[8] Dworkin stated that rights are what everyone should uphold. As Dworkin expressed, "Privileges are best perceived as trumps over some foundation avocation for political choices that the satay at objective for the local area all in all."[9]

Protection is a crucial element in rights, as Houwing argues, sees "rights as an interest that protected by law in a certain way." The law must consider interests carefully and strike a balance between them. Van Dijk in Peter Mahmud Marzuki states that "the law must function in achieving the goal of peace and prosperity, the aim of achieving peace and prosperity can be realized if the law provides as much as possible a fair arrangement. [10]

Legal protection for the safety of health workers is a crucial aspect of the COVID-19 pandemic. In practice, health workers often do not get the rights that should be fulfilled, such as the availability of personal protective equipment (PPE).[11] The public authority should likewise focus on the security of wellbeing laborers in managing the Covid-19 episode by meeting the accessibility of PPE. Legitimately, wellbeing laborers are furnished with commitments and lawful privileges and assurances managed in the enactment.

Based on Permenkes No. 66/2016 concerning Occupational Safety \& Health in Hospitals,[12] then health workers must also follow the occupational safety and health protocols while dealing with the covid-19 pandemic. The protocol guidelines are regulated in Permenkes No. 27/2017 on Guidelines for Infection Prevention \& Control in Health Facilities. Nonetheless, these arrangements don't unequivocally oversee the expected risk of spreading the Covid-19 infection. 
Concerning privileges of wellbeing laborers who are ensured by law. Consequently, alluding to Article 57 of the Law on Health Workers, it expressed that in completing their training, wellbeing laborers are qualified for: [12]

a. Acquire lawful insurance insofar as completing errands observing Professional Guidelines, Professional Service Standards, and Standard Operating Procedures;

b. Get total and right data from wellbeing administration beneficiaries or their families;

c. Receiving fees for services;

d. Get security for word related wellbeing and wellbeing, treatment following human nobility, ethics, tolerability, and strict qualities;

e. Get the opportunity to develop their profession;

f. Deny the desires of the beneficiary of wellbeing administrations or different gatherings that are in opposition to proficient principles, codes of morals, administration norms, standard working strategies, or arrangements of laws and guidelines; and

g. Get different freedoms following the arrangements of the enactment.

The above provisions provide a guarantee that health services are protected by law. The right to safety and job security when providing health services is guaranteed by law. Likewise, in an emergency such as the Covid-19 pandemic, guaranteeing legal protection in providing services to patients is very necessary for firmness and clarity of implementation. In health services during the Covid 19 Pandemic, many health workers had to work hard, and some even lost their lives in carrying out their duties.

Identified with this, the public authority is additionally liable for giving wellbeing administration offices to wellbeing laborers to do their work. In this manner, the Central Government and Regional Governments are liable for the accessibility of wellbeing administration offices to understand the most significant level of wellbeing. It is controlled and expressed in Article 6 of Government Regulation Number 47 of 2016 concerning Health Service Facilities.

Taking into account that the current Covid-19 flare-up has the situation with a debacle after the issuance of the Decree of the Head of National Board for Disaster Management (BNPB) Number 13 An of 2020 that all levels of the Government are needed to do every one of their commitments as specified in the appropriate enactment. The commitments that ought to be satisfied by this Government incorporate:

a. Backing the accessibility of clinical hardware in the field;

b. Guaranteeing the satisfaction of the freedoms of the local area and clinical staff;

c. Straightforwardness of data to people in general;

d. Making arrangements that focus on the upsides of basic freedoms and vote based system.

Therefore, the Government needs to seek legal protection and fulfill the ideal right to obtain work safety for medical personnel who are handling the COVID-19 pandemic as the front line in controlling the pandemic. In this case, protection is formulated with a responsive policy so that medical personnel can fulfill their rights proportionally.

\section{Conclusion}

In view of the conversation on the issue of legitimate assurance and the satisfaction of the option to acquire work security for clinical faculty who handle the COVID-19 pandemic, it tends to be presumed that it is directed in Minister of Health Regulation No. 66/2016 concerning Occupational Safety and Health in Hospitals, that wellbeing laborers should follow word related security and wellbeing conventions during the treatment of the Coronavirus 
pandemic. The convention rules are controlled in the Minister of Health Regulation No. 27/2017 concerning Guidelines for Infection Prevention and Control in Health Facilities. Nonetheless, these arrangements don't definitively manage the likely risk of spreading the Covid-19 infection.

\section{Referensi}

[1] A. G. Sari, H. L. Sudarmanto, and H. Murty, “ The Policy for Enforcement of Regional Quarantine as Anticipation of the Spread of the Corona Virus in terms of Law no. 6 of 2018 concerning Health Quarantine," J. Transparansi Huk., 2020.

[2] P. S. Saraswati, " Legal Policy on Handling the Covid-19 Pandemic in Indonesia," KERTHA WICAKSANA, vol. 14, no. 2, pp. 147-152, Jul. 2020, doi: 10.22225/kw.14.2.1923.147-152.

[3] D. Telaumbauna, “ Juridical Review on Determining Public Health Emergency Due to Covid-19," J. Educ. Dev., 2020.

[4] M. H. Dr. johnny ibrahim,SH., Normative Legal Research Theory \& Methodology. 2006.

[5] I. M. P. Diantha, “ Normative Legal Research Methodology,” Teor. Metodol. Penelit. a., 2017.

[6] M. Abdul Kadir, "Law And Legal Research.," Bandung PT. Citra Aditya Bakti., 2015.

[7] E. R. Pratiwi, M. Syahbandir, and A. Yahya, "Legal Protection of Patient Rights Users of Class 3 Social Security Administering Bodies," Syiah Kuala Law J., vol. 1, no. 1, pp. 119-139, 2018, doi: 10.24815/sklj.v1i1.12270.

[8] R. John, A Theory of Justice, Revised. Cambridge: The Belknap Press, 1999.

[9] B. M. Sholehah, U. Sudjana, and A. Suryaman, " PATIENT PROTECTION IN HEALTH SERVICES BY BPJS HEALTH FACILITY IN BANDUNG CITY IN CONNECTION WITH LAW NO. 24 YEAR 2011 CONCERNING SOCIAL SECURITY IMPLEMENTING AGENCY AND MINISTER OF HEALTH REGULATION NO. 71 YEAR 2013 CONCERNING K SERVICES,” Hermeneut. J. Ilmu Huk., vol. 4, no. 1, Feb. 2020, doi: 10.33603/hermeneutika.v4i1.3275.

[10] B. Anzward and M. Muslaini, " Principles of Justice in Fulfilling the Rights of Patients Recipient of Contribution Assistance for Health Social Security Administering Bodies," J. Facto, 2019.

[11] E. R. Pratiwi, M. Syahbandir, and A. Yahya, " Legal Protection of Patients' Human Rights Users of Class 3 Social Security Administering Bodies," Syiah Kuala Law J., vol. 1, no. 1, pp. 119-139, Nov. 2018, doi: 10.24815/sklj.v1i1.12270.

[12] “ Minister of Health Regulation Number 66 of 2016 concerning Occupational Safety \& Health in Hospitals". 